\title{
Using urine nitrite sticks to test for urinary tract infection in children aged $<2$ years: a meta-analysis
}

\author{
Malcolm G. Coulthard ${ }^{1}$ iD
}

Received: 12 January 2019 / Revised: 24 February 2019 / Accepted: 27 February 2019 / Published online: 20 March 2019

(C) The Author(s) 2019

\begin{abstract}
Background This study aimed to determine whether nitrite sticks are as sensitive at detecting urinary tract infection (UTI) in children $<2$ years as they are in older children.

Methods I reanalysed data on using nitrite sticks to detect UTIs for children aged either $<2$ or $2-18$ years. For sensitivity, evidence of a UTI was defined as level 1 when a single uropathogen grew $\geq 10^{5}$ colony forming units $/ \mathrm{ml}$ (cfu/ml) in two urine samples, level 2 when just one sample was cultured or a threshold of $<10^{5} \mathrm{cfu} / \mathrm{ml}$ was used, and level 3 if mixed growths or Staphylococcus albus was considered to be positive. For specificity, children were defined as uninfected if they had 1 sterile urine culture. I also reanalysed our previously published data by age.

Results The sensitivity was lower for children aged <2 years (11 studies, 1321 subjects) than for older children (9 studies, 295 subjects), whether the level-1 values or all the studies were analysed (Fisher's exact test, $p<0.0001$ for both). The level- 1 sensitivities were 0.23 in the infants and 0.81 among older children (odds ratio $=0.07,95 \%$ confidence interval $0.03-0.18$ ). The specificity was very high in infants (10 studies, 1783 cases) and older children (7 studies, 5952 cases), at 0.990 and 0.996.

Conclusions Nitrite sticks only have a $23 \%$ sensitivity in children aged $<2$ years, so cannot reliably rule out UTIs. A positive nitrite stick test is about $99 \%$ likely to indicate a UTI in children of any age.
\end{abstract}

Keywords Child $\cdot$ Urinary tract infection $\cdot$ Urine $\cdot$ Culture $\cdot$ Bacteria $\cdot$ Diagnosis $\cdot$ Nitrite $\cdot$ Stick testing

\section{Introduction}

Young children with urinary tract infections (UTIs) should be treated promptly with antibiotics to reduce sequelae $[1,2]$, and ideally within 3 days in infants $<2$ years of age to reduce their risk of developing permanent kidney scars [3, 4]. Because urine culture cannot provide immediate screening, it is important to find sensitive point-of-care tests that can identify infected urine samples rapidly and can help to decide whether to undertake a urine culture [5] or to commence antibiotic treatment. Nitrite sticks are the most convenient method of doing this.

Most uropathogens metabolise urinary nitrate to produce nitrite, which is not normally present in urine. This can be detected as a colour change in nitrite sticks if sufficient bacteria are incubated in urine long enough to produce recordable

Malcolm G. Coulthard

malcolm.coulthard@nuth.nhs.uk

1 Great North Children's Hospital, Queen Victoria Road, Newcastle upon Tyne NE1 4LP, UK and stable concentrations. Studies consistently report high specificity (few false positives) but record the widest range of sensitivities of any UTI screening test [1]. This is usually ascribed to short bacterial incubation times caused by urinary frequency, while other possibly important causes are ignored $[1,5-9]$. Children may not eat enough fruits or vegetables to provide sufficient urinary nitrate [10-12], and their nitrite ions may be unstable if their urine has a $\mathrm{pH}<6$, a sodium concentration $<40 \mathrm{mmol} / 1$ [13], or contains vitamin $\mathrm{C}[11,13]$ or urobilinogen [13]. These biochemical conditions are common in the young due to low salt intakes, high water turnover, and vitamin C supplements. I therefore reanalysed our paper [14] and reviewed other reports to compare nitrite stick testing separately for children under 2 and over 2 years of age.

\section{Methods}

I sourced papers where nitrite sticks were evaluated separately for infants aged $<2$ years and children aged $2-18$ years, from NICE guidelines [1] and a Medline (1946-August 2018) 
search, combining 'urinary tract infection or bacteriuria' and 'nitrite' in children ( $\leq 18$ years), and followed up earlier papers not included in computerised databases. I excluded children already known to have structural urinary tract abnormalities and included studies which compared urine collection methods in healthy individuals as well as those with a clinical suspicion of UTI. I also reanalysed the data our group has previously published on nitrite stick testing [14] to look for sex or age effects.

I recalculated the sensitivity results using the following diagnostic culture criteria for UTIs: quality level $1=\mathrm{a}$ single uropathogen in two urine samples at $\geq 10^{5}$ colony forming units $/ \mathrm{ml}(\mathrm{cfu} / \mathrm{ml})$; level $2=$ single uropathogen in one sample at $\geq 10^{5} \mathrm{cfu} / \mathrm{ml}$ or two samples at $<10^{5} \mathrm{cfu} / \mathrm{ml}$; level $3=$ mixed growths or skin commensals counted as positive. For specificity, children were considered infection free if they had at least one sterile urine, that is one which grew no bacteria in a petri dish $\left(<10^{3} \mathrm{cfu} / \mathrm{ml}\right)$. I tested for differences by age group using unpaired $t$ tests $(\mathrm{t})$ for individual-study data, and either $\chi^{2}$ or Fisher's exact test $(\mathrm{F})$ for pooled data, according to the dataset size. I compared the sensitivity odds ratios using a forest plot.

I produced leaf plots to demonstrate the usefulness of using nitrite stick tests for infants and older children [15]. These graphs are constructed from the sensitivity and specificity data of diagnostic tests and show the range of pre-test probabilities (how suspicious you were that the child had a UTI) along the diagonal 'vein' of the leaf. For any level of pre-test estimate of probability, the impact of a positive test result on that probability is shown by the vertical height upwards to the red line and the impact of a negative test is shown as the fall to the blue line below. A poor test will produce a narrow willow-type leaf pattern, while a powerful test will produce a broadleaf that nearly reaches the corners of the plot. New plots can be constructed for any diagnostic test data by accessing the free website www.childhealthafrica.org.

Table 1 Sensitivity and specificity values for nitrite stick testing, calculated for individual studies, presented in date order

\begin{tabular}{|c|c|c|c|c|c|c|c|c|c|}
\hline \multirow{2}{*}{\multicolumn{2}{|c|}{ Reference and year }} & \multirow[b]{2}{*}{ Reason for study } & \multirow[b]{2}{*}{ Age range } & \multicolumn{3}{|l|}{ Sensitivities } & \multicolumn{3}{|l|}{ Specificities } \\
\hline & & & & Sensitivity $^{\mathrm{a}}$ & $\begin{array}{l}\text { Evidence } \\
\text { Q-level }^{\mathrm{b}}\end{array}$ & $\begin{array}{l}\text { Valid cases } \\
(n)\end{array}$ & Specificity $^{\mathrm{a}}$ & $\begin{array}{l}\text { Evidence } \\
\text { Q-level }^{\mathrm{c}}\end{array}$ & $\begin{array}{l}\text { Valid cases } \\
(n)\end{array}$ \\
\hline \multicolumn{10}{|c|}{ Infants $<2$ years } \\
\hline 31 & 1985 & Screening & 3-28 months & & & & 0.993 & 1 & 439 \\
\hline 18 & 1991 & ?UTI & $<1.5$ year & 0.16 & 3 & 37 & & & \\
\hline 19 & 1993 & Screening & Newborns & 0.17 & 1 & 24 & 0.986 & 1 & 223 \\
\hline 20 & 1998 & ?UTI & $<1$ year & 0.447 & 2 & 237 & & & \\
\hline 16 & 1998 & ?UTI & $<1$ year & 0.1 & 2 & 7 & 0.99 & 1 & 115 \\
\hline 21 & 2001 & ?UTI & $<4$ years & 0.24 & 2 & 21 & 1.000 & 1 & 230 \\
\hline 22 & 2002 & ?UTI & $<2$ years & 0.35 & 2 & 23 & 0.98 & 1 & 170 \\
\hline 23 & 2008 & ?UTI & $<2$ years & 0.47 & 2 & 32 & 0.97 & 1 & 29 \\
\hline 14 & 2010 & ?UTI & $<2$ years & 0.5 & 1 & 6 & 0.96 & 1 & 45 \\
\hline 24 & 2014 & ?UTI & Median 6.2 months & 0.52 & 2 & 42 & 0.993 & 1 & 300 \\
\hline 26 & 2015 & ?UTI & $<3$ months & 0.395 & 2 & 243 & 1.00 & 1 & 115 \\
\hline 25 & 2015 & ?UTI & $<3$ months & 0.371 & 2 & 649 & 0.99 & 1 & 117 \\
\hline \multicolumn{10}{|c|}{ Older children } \\
\hline 27 & 1974 & Screening & $8-11$ years & 0.92 & 1 & 25 & 0.998 & 1 & 3494 \\
\hline 28 & 1977 & ?UTI & Pre-school & 0.70 & 1 & 42 & 1.00 & 1 & 55 \\
\hline 12 & 1978 & ?UTI & $2-18$ years & 0.93 & 1 & 30 & & & \\
\hline 29 & 1978 & Screening & $5-12$ years & 0.60 & 1 & 15 & 1.000 & 1 & 1043 \\
\hline 17 & 1982 & ?UTI & $2-15$ years & 0.56 & 3 & 101 & 0.999 & 1 & 923 \\
\hline 17 & 1982 & ?UTI & $2-15$ years & 0.88 & 3 & 41 & & & \\
\hline 30 & 1998 & Screening & $5-14$ years & 0.60 & 2 & 15 & 0.98 & 1 & 171 \\
\hline 16 & 1998 & ?UTI & $1-18$ years & 0.6 & 2 & 9 & 0.96 & 1 & 194 \\
\hline 14 & 2010 & ?UTI & $2-18$ years & 0.94 & 1 & 17 & 0.97 & 1 & 72 \\
\hline
\end{tabular}

${ }^{a}$ Calculated values are expressed to 1 significant figure when $n<10$, to 2 sf when $n=10<200$, and to 3 sf when $n \geq 200$

${ }^{\mathrm{b}}$ Sensitivity evidence levels detailed in text. Summary: $1=2$ cultures of $\geq 105 / \mathrm{ml}, 2=1$ culture or threshold of $104 / \mathrm{ml}, 3=$ included mixed growths or non-uropathogens as culture positive. ${ }^{\mathrm{c}}$ Specificity evidence levels $=$ at least one sterile sample 


\section{Results}

\section{Material}

Eighteen papers provided sufficient age group-specific data to allow me to calculate their sensitivity or specificity values for infants $<2$ years or older children separately, of which two enrolled children from both age groups [14, 16], and one included two sub-sets of older children [17], resulting in a total of 21 informative data sets (Table 1). Eleven studies provided sensitivity data for infants $[14,16,18-26]$, and eight for older children $[12,14,16,17,27-30]$, while ten papers provided specificity data for infants $[14,16,19,21-26,31]$, and seven for older children $[14,16,17,27-30]$.

Level-1 sensitivity evidence was provided for $2 / 11$ studies of infants and 5/9 for older children. Six level2 studies of sensitivity had used a single sample [16, $20,21,25,26,30]$, one had used a $10^{4} \mathrm{cfu} / \mathrm{ml}$ threshold [22], and two had done both [23, 24]. One grade-3 paper had counted mixed growths [18], and one included Staphylococcus albus cultures [17] as positive. In three papers which had previously used lower diagnostic thresholds [16, 20, 21], I recalculated their data using $\geq$ $10^{5} \mathrm{cfu} / \mathrm{ml}$. I rejected one study that had counted proteus contamination as UTI [31], another because of unacceptable design features [32], one because of selection bias [18], and one because the data was insufficient to reanalyse [33].

\section{Sensitivity}

The individual study mean sensitivity values were all lower in infants than in older children (see Table 1 and Fig. 1; t, $p<0.0001$ ). The same was true for sensitivity data that was pooled from all the studies (Table 2). At level-1 quality, only 7/30 infants with UTIs had positive nitrite sticks, compared to $105 / 129$ older children, giving sensitivity values of 0.23 vs 0.81 (F, $p<0.0001)$. The level-2 and level-3 quality data showed the same relationship (F, $p<0.0001$ in each case), as shown by a forest plot of their odds ratios (Fig. 2). The two studies which tested both age groups $[14,16]$ are also shown in this plot.

\section{Specificity}

Every study had high specificity values (Table 1 and Fig. 1), with no detectable age effect using unpaired $t$ testing $(\mathrm{t}, p=$ $0.95)$. The pooled specificity values were 0.990 for 1783 infants and 0.996 for 5952 older children (Table 2), equivalent to false-positive rates of $1.0 \%$ in infants and $0.4 \%$ in the older children $\left(\chi^{2}, p<0.002\right)$. This statistically significant difference is too small to be of clinical importance.

\section{Leaf plot}

Leaf plots aid the interpretation of positive or negative nitrite stick test results, according to the clinical pre-test probability of that individual child having a UTI, which should be read
Fig. 1 Plot of sensitivity and specificity data for individual studies of using nitrite sticks to detect UTIs in infants aged $<$ 2 years compared with older children. Data quality levels: $1=$ red, $2=$ blue, $3=$ green. The $p$ values refer to unpaired $t$ test results
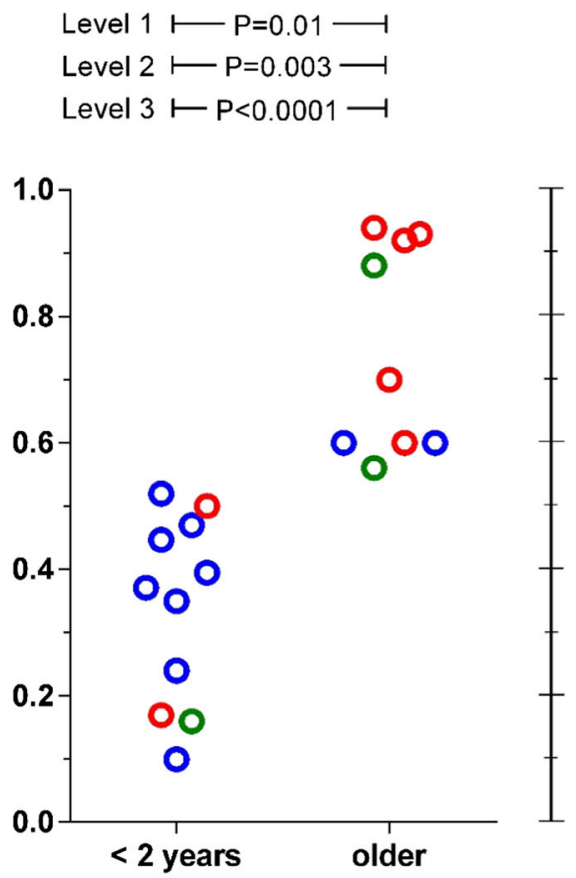

Sensitivity
Level $1 \longmapsto P=0.7 \longrightarrow$

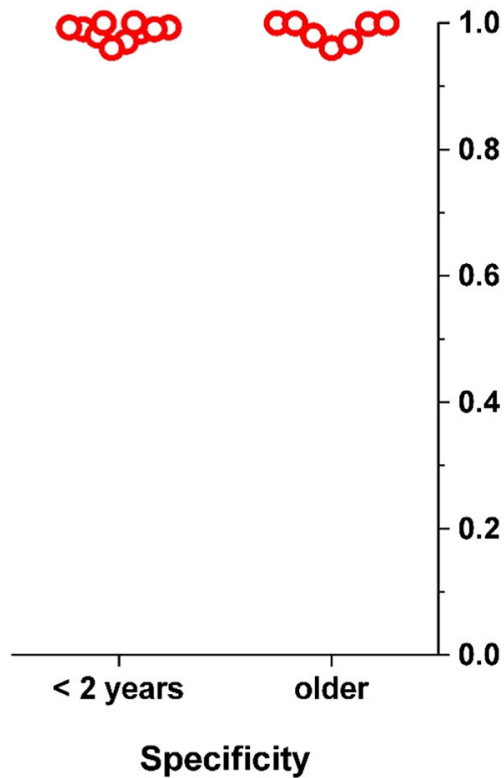


Table 2 Sensitivity and specificity values of the pooled data from studies of nitrite stick testing, according to age range and the evidence quality

\begin{tabular}{|c|c|c|c|c|c|c|c|c|c|}
\hline \multirow{3}{*}{$\begin{array}{l}\text { Evidence } \\
\text { level }\end{array}$} & \multicolumn{4}{|c|}{ Studies of infants } & \multicolumn{4}{|c|}{ Studies of older children } & \multirow{3}{*}{$\begin{array}{l}\text { Difference by age } \\
\text { Contingency table } \\
\text { analysis } \\
\text { ( } p \text { value) }\end{array}$} \\
\hline & \multicolumn{2}{|c|}{ Studies } & \multirow{2}{*}{$\begin{array}{l}\text { Cases } \\
(n)\end{array}$} & \multirow{2}{*}{$\begin{array}{l}\text { Sensitivity or } \\
\text { specificity }\end{array}$} & \multicolumn{2}{|c|}{ Studies } & \multirow{2}{*}{$\begin{array}{l}\text { Cases } \\
\text { (n) }\end{array}$} & \multirow{2}{*}{$\begin{array}{l}\text { Sensitivity or } \\
\text { specificity }\end{array}$} & \\
\hline & $(n)$ & (References) & & & (n) & (References) & & & \\
\hline \multicolumn{10}{|l|}{ Sensitivity } \\
\hline Level 1 only & 2 & {$[14,19]$} & 30 & 0.23 & 5 & {$[12,14,27-29]$} & 129 & 0.81 & $<0.0001^{\mathrm{F}}$ \\
\hline $\begin{array}{l}\text { Levels } 1 \text { and } \\
2\end{array}$ & 10 & {$[14,16,19-26]$} & 1284 & 0.38 & 7 & {$[12,14,16,27-30]$} & 153 & 0.78 & $<0.0001^{\mathrm{F}}$ \\
\hline All 3 levels & 11 & {$[14,16,18-26]$} & 1321 & 0.38 & 9 & $\begin{array}{l}{[12,14,16,17,} \\
27-30]\end{array}$ & 259 & 0.72 & $<0.0001^{\mathrm{F}}$ \\
\hline \multicolumn{10}{|l|}{ Specificity } \\
\hline Level 1 & 10 & $\begin{array}{l}{[14,16,19,22-26} \\
\quad 31]\end{array}$ & 1783 & 0.990 & 7 & {$[14,16,17,27-30]$} & 5952 & 0.996 & $0.002^{x}$ \\
\hline
\end{tabular}

${ }^{\mathrm{F}}$ Fisher's exact test. ${ }^{\chi}$ Chi-square test

from the appropriate position along the diagonal 'vein' of the leaf (Fig. 3) [15]. If nitrite testing was used to screen healthy children for asymptomatic UTI, the pre-test probability would be read from the bottom left of the vein; for a child with an unexplained fever, it would be read about half-way along; and for a febrile child with frequent previous UTIs and offensivesmelling urine, it would be read from near the top right corner. The extra impact of a positive nitrite test is to elevate the chances of a UTI diagnosis to the level of the red line, and of a negative one is to reduce it to the level of the blue line.

The plots in Fig. 3 confirm that a positive nitrite stick test in a child over 2 years old is a powerful indicator that they have a UTI, at almost every level of prior probability, and a fairly powerful indicator in infants. The older children's plot shows that a negative nitrite result is moderately helpful in ruling out a UTI after 2 years of age, which may be clinically useful as they typically have a low risk of developing kidney scars from a missed first infection [34]. However, the infant plot shows that a negative nitrite stick result has virtually no value for ruling out UTIs in the very young (note the small blue area below the leaf 'vein').

\section{Discussion}

\section{Excluding the diagnosis of a UTI in infants}

This reanalysis shows that urine nitrite stick tests miss UTIs in about three quarters of children aged $<2$ years, probably due to a combination of low dietary nitrate $[10$, 11], the instability of their urinary nitrite [11, 13], and urinary frequency $[5-7,33]$. This means that it is unsafe to rely on negative nitrite stick test results to decide which infants to treat promptly, which is unfortunate because they are very convenient [5], especially in primary care [35]. Yet, it is important to commence antibiotics before the culture results are available (typically 3 or 4 days later [35]) as this reduces the risk of infants developing kidney scars $[3,4]$. Reliable alternative tests that can be carried out at the point-of-care include phase-contrast microscopy of fresh urine [14], or even Gram-staining [22], but another option is to commence antibiotics on clinical suspicion and then discontinue them in culture-negative cases [3]. Older children at particular risk of scarring, for example because they are known to have persistent vesicoureteric reflux [3, 4], should be treated in the same way as infants.

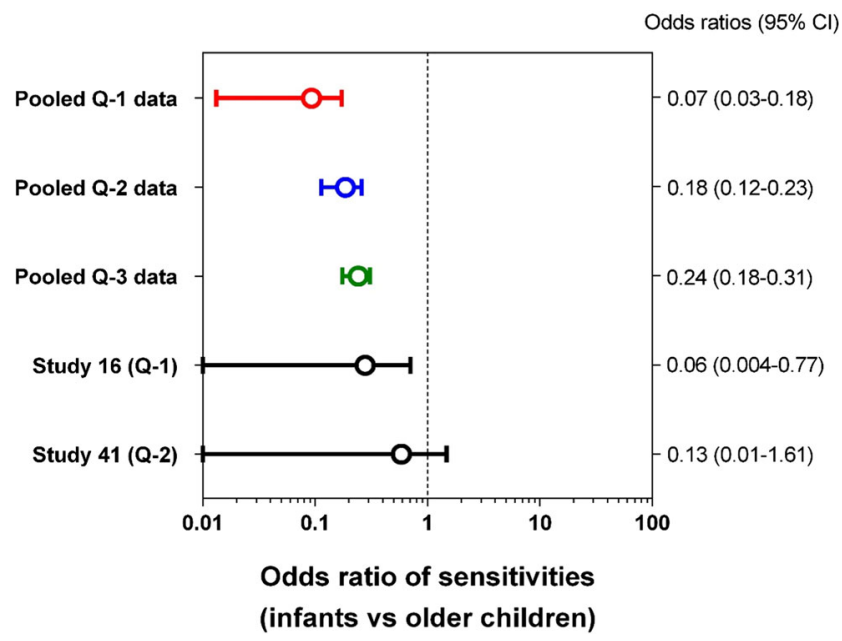

Fig. 2 Forest plot of the sensitivity odds ratios and 95\% confidence intervals of the ability of nitrite sticks to detect UTIs in infants aged < 2 years compared with older children. Data quality levels for pooled data: $1=$ red, 2 =blue, $3=$ green. Also, the results are shown for two studies that each tested children in both age groups 


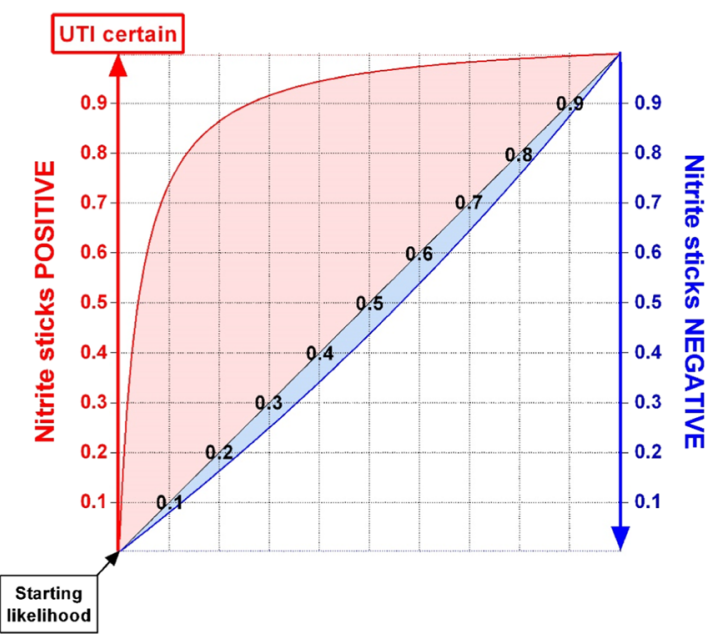

Infants aged $<2$ years

Fig. 3 Leaf plots showing the diagnostic value of nitrite stick testing to detect urinary tract infections (UTIs) in infants aged $<2$ years and for older children. The vertical increase in height of the red line above the diagonal (vein of the 'leaf') shows the impact that a positive culture result

\section{Study limitations}

Calculated sensitivity data for any test will be falsely low if the new method is tested against 'gold-standard' techniques which themselves produce false-positive results. This has been the case in some previous nitrite stick studies, where the reference culture data has been less rigorous than the quality level-1 definitions I have used [14]. However, in this metaanalysis, nitrite stick sensitivity was confirmed to be low in infants whichever quality level of evidence we used. The analysis would have been more robust if more than just two source papers had each investigated both infants and older children $[14,16]$, rather than us having to make agegroup comparisons between different publications. However, the difference between the age groups was so large that it was clear despite these shortcomings.

\section{Age ranges tested}

I imposed an arbitrary age cut-off at 2 years, though it is physiologically implausible that the sensitivity of nitrite stick testing would change suddenly at this point. However, it was necessary to define a clinically relevant threshold, and children younger than this are particularly vulnerable to develop scars after a UTI $[1,3,4]$. Other age ranges may also be interesting to investigate. Our previous study [14] suggests that nitrite sticks may be most sensitive in 2 to 9 -year-olds $(16 / 17$; 0.94), but less sensitive in both infants $(3 / 6 ; 0.5$ : $\mathrm{F}$, $p=0.04)$, and in older girls $(8 / 13 ; 0.62: \mathrm{F}, p=0.06)$ who may acquire UTIs with non-nitrate-reducing Enterococcus sp. [36]. It might be easier to investigate how nitrite stick sensitivity

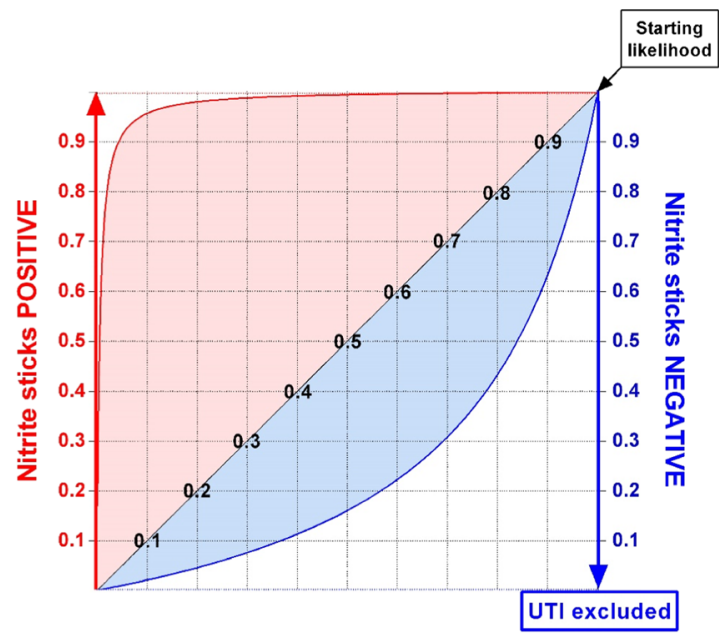

Older children

has on the probability of that child having a UTI. The vertical drop from the 'vein' to the blue line indicates the effect of a negative urine culture on excluding a UTI

varies with age in vitro by inoculating $E$. coli into urine specimens collected from healthy children.

\section{Conclusions}

It is not safe to use nitrite sticks to screen children aged $<2$ years for UTIs because they would miss about three quarters of positive cases, though they are useful at some ages, such as between 2 and 9 year of age. This is unfortunate because infants carry the greatest risk of developing kidney scars if they are not treated for UTIs within 3 days. By contrast, a positive nitrite result is very likely to indicate a true UTI at any age.

\section{Compliance with ethical standards}

Conflict of interest The author declares that he has no conflict of interests.

Open Access This article is distributed under the terms of the Creative Commons Attribution 4.0 International License (http:// creativecommons.org/licenses/by/4.0/), which permits unrestricted use, distribution, and reproduction in any medium, provided you give appropriate credit to the original author(s) and the source, provide a link to the Creative Commons license, and indicate if changes were made.

\section{References}

1. National Institute for Health and Clinical Excellence (NICE) (2007) Urinary tract infection in children. http://guidance.nice.org.uk/ CG054. Accessed 4 Jan 2019 
2. American Academy of Pediatrics (2011) Urinary tract infection: clinical practice guideline for the diagnosis and management of the initial UTI in febrile infants and children 2 to 24 months. Pediatr 128:595-610

3. Coulthard MG, Lambert HJ, Vernon SJ, Hunter EW, Keir M, Matthews JNS (2014) Does prompt treatment of urinary tract infection in preschool children prevent renal scarring: mixed retrospective and prospective audits. Arch Dis Child 99:342-347

4. Karavanaki KA, Soldatou A, Koufadaki AM, Tsentidis C, Haliotis FA, Stefanadis CJ (2017) Delayed treatment of the first febrile urinary tract infection in early childhood increased the risk of renal scarring. Acta Paediatr 106:149-154

5. Mori R, Yonemoto N, Fitzgerald A, Tullus K, Verrier-Jones K, Lakhanpaull M (2010) Diagnostic performance of urine dipstick testing in children suspected with UTI: a systematic review of relationship with age and comparison with microscopy. Acta Paediatr 99:581-584

6. Alwall N, Lohi A (1973) Factors affecting the reliability of screening tests for bacteriuria. Acta Med Scand 193:499-503

7. Powell HR, McCredie DA, Ritchie MA (1987) Urinary nitrite in symptomatic and asymptomatic urinary infection. Arch Dis Child 62:138-140

8. Shaw KN, Hexter D, McGowan KL, Schwartz JS (1991) Clinical evaluation of a rapid screening test for urinary tract infections in children. J Pediatr 118:733-736

9. Cyriac J, Holden K, Tullus K (2017) How to use... urine dipsticks. Arch Dis Child Educ Pract Ed 102:148-154

10. Tahirovic H, Pasic M (1988) A modified nitrite test as a screening test for significant bacteriuria. Eur J Pediatr 147:632-633

11. Bednar C, Kies C (1994) Nitrate and vitamin C from fruits and vegetables: impact of intake variations on nitrate and nitrite excretion of humans. Plant Foods Hum Nutr 45:71-80

12. Scheifele DW, Smith AL (1978) Home-testing for recurrent bacteriuria, using nitrite strips. Am J Dis Child 132:46-48

13. James GP, Paul KA, Fuller JB (1978) Urinary nitrite and urinarytract infection. Am J Clin Pathol 70:671-678

14. Coulthard MG, Nelson A, Smith T, Perry JD (2010) Point-of-care diagnostic tests for childhood urinary tract infection: phase-contrast microscopy for bacteria, stick-testing, and counting white blood cells. J Clin Pathol 63:823-829

15. Coulthard MG, Coulthard T (2019) The leaf plot: a novel way of presenting the value of tests. Br J Gen Pract. https://doi.org/10. 3399/bjgp18XXXXXXX

16. Sharief N, Hameed M, Petts D (1998) Use of rapid dipstick tests to exclude urinary tract infection in children. Br J Biomed Sci 55:242-246

17. Labbe J (1982) Usefulness of testing for nitrites in the diagnosis of urinary infections in children. Union Med Can 111:261-265

18. Lejeune B, Baron R, Guillois B, Mayeux D (1991) Evaluation of a screening test for detecting urinary tract infection in newborns and infants. J Clin Pathol 44:1029-1030

19. Demi M, Costa L, Zanardo V (1993) Urinary tract infections in newborns: sensitivity, specificity, and predictive value of urinary screening with the reagent strip test. Pediatr Med Chir 15:29-31

20. Hansson S, Brandstrom P, Jodal U, Larsson P (1998) Low bacterial counts in infants with urinary tract infection. J Pediatr 132:180-182
21. Armengol CE, Hendley JO, Schlager TA (2001) Should we abandon standard microscopy when screening for urinary tract infections in young children. Pediatr Infect Dis J 20:1176-1177

22. Dayan PS, Bennett J, Best R, Bregstein JS, Levine D, Novick MK, Sonnett FM, Stimell-Rauch ML, Urtecho J, Wagh A, Miller SZ (2002) Test characteristics of the urine gram stain in infants less than 60 or 60 days of age with fever. Pediatr Emerg Care 18:12-14

23. Gilljam B-M, Svensson M-L (2008) In-out catheterization of young children with suspected urinary tract infection: a retrospective journal study. Pediatr Nurs 34:241-245

24. Kanegaye JT, Jacob JM, Malicki D (2014) Automated urinalysis and urine dipstick in the emergency evaluation of young febrile children. Pediatr 134:523-529

25. Schroeder AR, Chang PW, Shen MW, Biondi EA, Greenhow TL (2015) Diagnostic accuracy of the urinalysis for urinary tract infection in infants $<3$ months of age. Pediatr 135:965-971

26. Velasco R, Benito H, Mozun R, Trujillo JE, Merino PA, de la Torre M, Gomez B (2015) Using a urine dipstick to identify a positive urine culture in young febrile infants is as effective as in older patients. Acta Paediatr 104:e39-e44

27. Randolph MF, Morris K (1974) Instant screening for bacteriuria in children: analysis of a dipstick. J Pediatr 84:246-248

28. Kunin CM, DeGroot JE (1977) Sensitivity of a nitrite indicator strip method in detecting bacteriuria in preschool girls. Pediatr 60:244

29. Sinaniotis CA, Haratsaris MN, Papadatos CJ (1978) Nitrite indicator strip test for bacteriuria. Lancet 1:776-777

30. Munyi ST, Macharia WM, Alwar AJ, Njeru EK (1998) Screening for urinary tract infection in children with cancer. East Afr Med J 75:264-267

31. Goosens H, De Mol P, Hall M, Butzler JP (1985) Prevalence of asymptomatic bacteriuria and comparison between different screening methods for its detection in infants. Eur J Epidemiol 1:301.304

32. Iitaka K, Oyama K, Sakai T, Izawa T, Tomuro M, Kanai K, Isozaki A, Igarashi S (1984) Screening for bacteriuria in healthy Japanese school children. Int J Pediatr Nephrol 5:159-162

33. Herreros ML, Tagarro A, Garcia-Pose A, Sanchez A, Canete A, Gili P (2018) Performing a urine dipstick test with a clean-catch urine sample is an accurate screening method for urinary tract infections in young infants. Acta Paediatr 107:145-150

34. Vernon SJ, Coulthard MG, Lambert HJ, Keir MJ, Matthews JNS (1997) New renal scarring in children who at age 3 and 4 years had had normal scans with dimercaptosuccinic acid: follow up study. BMJ 315:905-908

35. Vernon S, Foo CK, Coulthard MG (1997) How general practitioners manage children with urinary tract infection: an audit in the former northern region. Br J Gen Pract 47:297-300

36. Coulthard MG, Kalra M, Lambert HJ, Nelson A, Smith T, Perry JD (2010) Redefining urinary tract infections by bacterial colony counts. Pediatr 125:335-341

Publisher's note Springer Nature remains neutral with regard to jurisdictional claims in published maps and institutional affiliations. 